\title{
SURVEY PERILAKU MASYARAKAT TERHADAP POPULASI TUNGAU DEBU RUMAH DI SEKITAR RUMAH PENDUDUK KELURAHAN RANOTANA WERU KECAMATAN WANEA
}

\author{
${ }^{1}$ Winner S.Tjandra \\ ${ }^{2}$ Janno B.Bernadus \\ ${ }^{2}$ Josef.S.B.Tuda
}

\author{
${ }^{1}$ Mahasiswa Fakultas Kedokteran Universitas Sam Ratulangi Manado \\ ${ }^{2}$ Bagian Parasitologi Fakultas Kedokteran Universitas Sam Ratulangi Manado \\ Email: Win_Tjandra@outlook.com
}

\begin{abstract}
House Dust Mites are found in damp houses, mattresses, pillows, bolsters, carpets as well as the other variety of home furnishings. House Dust Mites can be a serious problem for human health. For people who are susceptible to house dust mites can trigger allergic reactions such as asthma, rhinitis, conjunctivitis and atopic dermatitis. The location of the research was held in Ranotana Village of Wanea District. In this location there are many home stay, that most of the residents has less attention to the hygiene of their rooms. Purpose of this thesis research is to find a picture of the behavior the society courses on house dust mites araound the house people in Ranotana Village of Wanea District. Advance research methodsin use is a descriptive study using a questionnaire survey method. Sample is determined by simple random sampling method. Number of sampe in this study as many as 95 house holder and were collected using a questionnaire containing a list of questions. Based on research done the people in Ranotana Village of Wanea District has the poor level of knowledge, in attitude most have good attitude, and have good in action.
\end{abstract}

Keywords: Behavior, House Dust Mites, Population

\begin{abstract}
Abstrak: Tungau Debu Rumah banyak ditemukan pada rumah yang lembab, kasur, bantal, guling, karpet serta berbagai perabot rumah yang lain.TDR dapat menjadi masalah yang serius bagi kesehatan manusia. Bagi orang yang rentan TDR dapat menjadi pencetus timbulnya reaksi alergi seperti asma, rhinitis, konjungtivitis dan dermatitis atopik. Lokasi penelitian dilakukan di Kelurahan Ranotana Weru Kecamatan Wanea. Lokasi ini banyak terdapat rumah kost, dimana sebagian besar penghuni kost kurang memperhatikan kebersihan kamarnya. Tujuan penelitian ini adalah mencari gambaran perilaku masyarakat terhadap populasi tungau debu rumah di sekitar rumah penduduk Kelurahan Ranotana Weru Kecamatan Wanea. Metode penelitian yang digunakan adalah penelitian deskriptif dengan metode survey menggunakan kusioner, sampel dalam penelitian ini sebanyak 95 Kepala Keluarga dan dikumpulkan dengan menggunakan kusioner yang berisikan pertanyaan. Berdasarkan hasil penelitian yang dilakukan penduduk Kelurahan Ranotana Weru Kecamatan Wanea masih memiliki pengetahuan yang kurang baik, dalam hal sikap memiliki sikap yang baik, dan dalam hal tindakan memiliki tindakan yang baik.

Kata Kunci : Perilaku, Tungau Debu Rumah, Populasi
\end{abstract}

Debu rumah, bagi sekelompok orang tertentu merupakan komponen alergen inhalan yang penting karena berperan terhadap timbulnya reaksi alergi seperti asma, dermatitis kontak, konjungtivitis, dan rhinitis. ${ }^{1}$
Di dalam debu rumah terdapat Tungau Debu Rumah (TDR). TDR ini banyak ditemukan pada rumah yang lembab, kasur, bantal, guling, karpet serta berbagai perabot rumah yang lain. Populasi TDR terbanyak 
didapatkan pada debu kamar tidur terutama pada debu kasur. ${ }^{1}$

Di Indonesia, sebagian besar masyarakatnya masih menggunakan kasur berbahan kapuk sebagai alas tidurnya walaupun sudah banyak juga yang beralih ke kasur berbahan non kapuk seperti kasur busa, kasur pegas, dan kasur lateks. Kasur merupakan habitat terbaik yang cocok untuk perkembangan TDR. TDR menyukai lingkungan yang hangat dan lembab seperti di dalam kasur. Selain itu pada kasur juga tersedia makanan TDR (reaksi antara kasur, keringat, daki serta serpihan kulit manusia). ${ }^{1,2}$

Masyarakat Indonesia rata-rata tidur 68 jam sehari, hal ini berarti dalam sehari selama itu pula mereka berada di kamar tidur dan melakukan kontak dengan kasur sehingga apabila kasur tercemar oleh TDR, maka lebih kurang sepertiga masa hidupnya mereka melakukan kontak dengan TDR. Bagi orang yang tidak sensitif hal tersebut tidak menjadi masalah tetapi bagi orang yang sensitif ini merupakan masalah serius karena bisa menjadi pencetus timbulnya reaksi alergi seperti asma, dermatitis, konjugtivitis, dan rhinitis. ${ }^{1,4}$ Di Sulawesi Utara khususnya daerah Manado, dari hasil pemantauan penulis sendiri jumlah rumah kost sangat banyak,dimana sebagian besar dari penghuni kost malas menjaga kebersihan kamarnya, hal itu dapat meningkatkan populasi tungau debu di kamar penghuni kost tesebut.

\section{METODE PENELITIAN}

Penelitian ini menggunakan penelitian deskriptif dengan menggunakan kusioner yang dibagikan kepada masyarakat Kelurahan Ranotana Weru Kecamatan Wanea. Jumlah sampel yaitu 95 Kepala Keluarga yang dihitung dengan menggunakan rumus Slovin menurut Notoadmodjo.

Hasil penelitian akan didistribusikan kedalam tabel microsoft excel dan akan dianalisis dengan program SPSS.

\section{HASIL PENELITIAN}

Pada penelitian ini responden yang sebanyak 95 Kepala Keluarga diberikan kusioner yang berisikan pertanyaan yang terbagi atas Pengetahuan, Sikap dan Tindakan.

\section{Pengetahuan responden}

Pertanyaan pada bagian ini meliputi 8 (delapan) pertanyaan seputar pengetahuan responden tentang tungau debu dan cara menjaga kebersihan untuk mengurangi populasi tungau debu. Kemudian diolah dengan menggunakan sistem scoring skala thurstone dan pengolahan data frekuensi menggunakan spss.



Gambar 1. Grafik pengetahun responden.

Dari Gambar 1, dapat dilihat grafik pengetahuan responden,dimana setelah dilakukan penelitian menggunakan kusioner, penulis mendapatkan hasil bahwa pengetahuan responden yang memiliki pengetahuan responden yang Baik berjumlah 33 orang (34,7\%), Cukup berjumlah 22 orang (23,2\%), dan Kurang Baik berjumlah 40 orang (42,1\%).

\section{Sikap responden}

Pertanyaan pada bagian ini meliputi 7 (tujuh) pertanyaan seputar sikap responden dalam menjaga kebersihan untuk mengurangi populasi tungau debu. Kemudian diolah dengan menggunakan sistem skoring skala thurstone dan pengolahan data frekuensi menggunakan spss. 


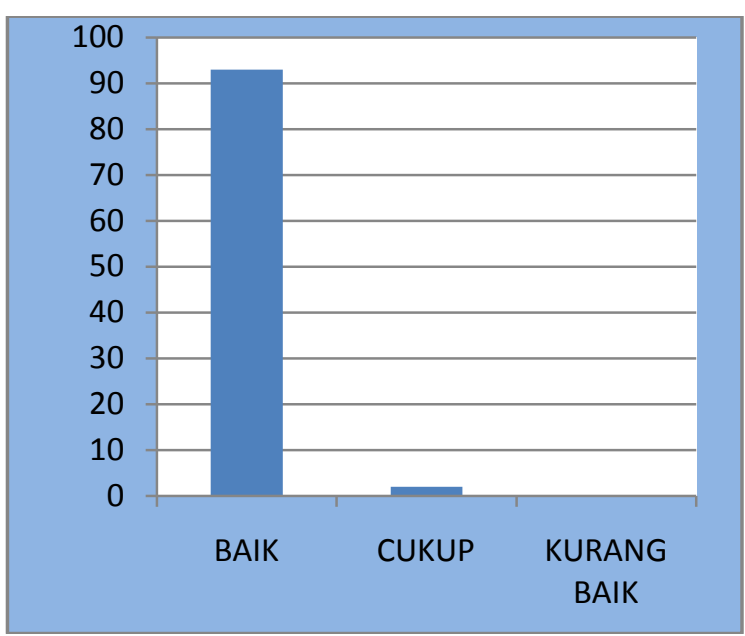

Gambar 2. Grafik sikap responden.

Dari Gambar 2, dapat dilihat grafik sikap responden,dimana setelah dilakukan penelitian menggunakan kusioner,penulis mendapatkan hasil bahwa sikap responden yang memiliki sikap responden yang Baik berjumlah 93 orang (97,9\%), Cukup berjumlah 2 orang (2,1\%), dan Kurang Baik berjumlah 0 orang $(0 \%)$.

\section{Tindakan responden}

Pertanyaan pada bagian ini meliputi 10 (sepuluh) pertanyaan seputar tindakan responden terhadap populasi tungau debu dan menanggulangi penyakit yang diakibatkan oleh TDR. Kemudian diolah dengan menggunakan sistem skoring skala thurstone dan pengolahan data frekuensi menggunakan spss.

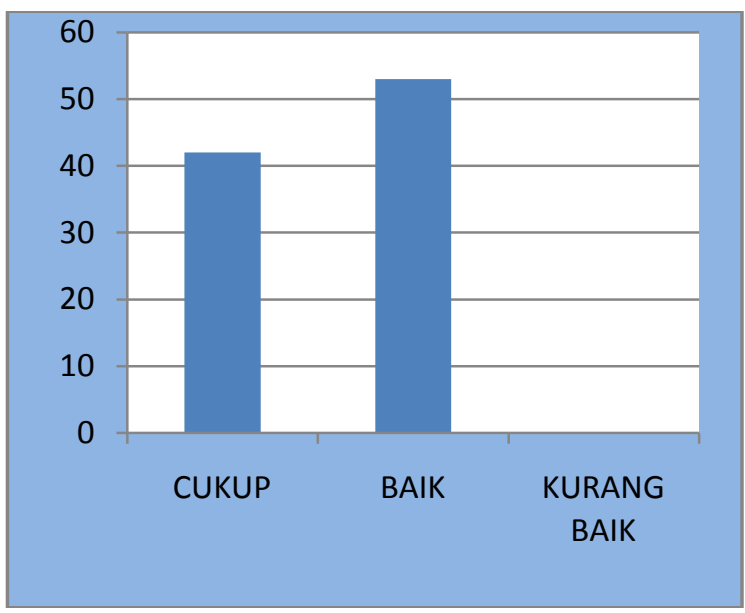

Gambar 3. Grafik tindakan responden.
Dari Gambar 2, dapat dilihat grafik tindakan responden,dimana setelah dilakukan penelitian menggunakan kusioner, penulis mendapatkan hasil bahwa tindakan responden yang memiliki tindakan responden yang Baik berjumlah 53 orang (55,8\%), Cukup berjumlah 42 orang (44,2\%), dan Kurang Baik berjumlah 0 orang (0\%).

\section{BAHASAN}

\section{Pengetahuan responden}

Dari hasil penelitian, diperoleh data bahwa sebagian besar responden belum mendapatkan informasi tentang tungau debu rumah,dimana 58 responden $(61,1 \%)$ menjawab tidak pernah mendapatkan informasi. Hal ini tentu patut menjadi perhatian pemerintah terutama petugas kesehatan untuk lebih giat melakukan penyuluhan tentang tungau debu rumah.

Dari hasil penelitian juga ditemukan bahwa sebanyak 43 orang $(45,3 \%)$ dari responden tidak mengetahui bahwa tungau debu berbahaya pada orang yang sensitive saja, hal ini menyebabkan beberapa orang berpendapat bahwa penyakit asma yang disebabkan oleh alergi merupakan penyakit menular dari orang lain, merupakan penyakit keturunan saja, dan tidak dapat disembuhkan.

Dari hasil penelitian ditemukan bahwa sebanyak 54 orang $(56,85)$ dari responden mengetahui bahwa habitat dari tungau debu adalah kebanyakan di Kasur kapuk, sprei, karpet, dan sofa.Dalam hal ini pengetahuan responden cukup baik. Pentingnya pengetahuan ini dikarenakan Desain dan perabot rumah tangga seperti kasur kapuk, karpet kain yang berbulu, sofa busa dan gorden kain yang berbulu dapat mempengaruhi banyak sedikitnya debu pada rumah. Debu pada rumah akan mengendap/ menempel di permukaan-permukaan seperti karpet, kasur, bantal gorden atau sofa. Jika tidak dibersihkan secara rutin maka debu akan menumpuk dan jumlah debu akan semakin bertambah dan sukar untuk dibersihkan.,

Dari hasil penelitian juga ditemukan bahwa sebanyak 45 orang $(47,4 \%)$ dari responden menjawab tidak tahu ukuran dari 
tungau debu tersebut, dan sisanya menjawab salah yaitu besar (seukuran kecoa) 1 orang $(1,1 \%)$, kecil (seukuran nyamuk atau semut kecil) 16 orang (16,8\%). Hal ini dikarenakan kebanyakan dari responden berasumsi bahwa tungau debu rumah itu sama dengan kutu busuk atau disebut juga Cimex lectularius yang merupakan serangga parasit dari keluarga Cimicidae, dimana Cimex lectularius tersebut berukuran Dewasa tumbuh 4-5 mm panjang dan lebar 1,5-3 mm sehingga dapat dilihat dengan mata telanjang. ${ }^{6,7}$

Pada penelitian ini responden yang menjawab cara pemberantasan tungau debu rumah dengan mejaga kebersihan sebanyak 60 orang (63,2\%), dengan melakukan penyemprotan insektisida 2 orang (2,1\%), dengan cara lain 2 orang (2,1\%), dan tidak tahu 31 orang (32,6\%). Dari hasil ini menunjukkan pengetahuan responden tentang cara pemberantasan tungau debu cukup baik.

\section{Sikap responden}

Dari hasil penelitian didapatkan bahwa sikap responden dalam membersihkan perabot rumah dengan lap basah yaitu Setuju berjumlah 32 orang (33,7\%), Tidak Setuju 24 orang (25,3\%), Ragu-Ragu 7 orang (3,4\%), Tidak Tahu (Tidak Mempunyai Sikap) 32 orang (33,7\%). Hal ini menunjukkan bahwa masih kurangnya penggunaaan lap basah dalam membersihkan perabot, padahal penggunaan lap basah dapat mengurangi paparan debu yang ada pada perabot, berbeda dengan penggunaan kemoceng yang tidak menghilangkan debu tetapi menerbangkannya ke tempat sekitarnya. ${ }^{5}$

Dari hasil penelitian juga ditemukan bahwa sikap responden dalam mengganti seprei dan sarung bantal seminggu sekali yaitu Setuju 90 orang (94,7\%), Tidak Setuju 3 orang (3,2\%), Ragu-ragu 2 orang (2,1\%). Dari data ini menunjukkan sikap positif responden dalam mengganti seprei dan sarung bantal seminggu sekali, hal ini juga direkomendasikan oleh U.S. Department of health and human services untuk mengurangi populasi tungau debu rumah.

\section{Tindakan responden}

Dari hasil penelitian didapatkan bahwa, tindakan responden ketika anggota keluarga atau tetangga menderita penyakit alergi tungau debu yaitu segera dibawa ke rumah sakit atau puskesmas terdekat berjumlah 60 orang (63,2\%), mencoba mengobati sendiri (karena sudah ada obatnya) berjumlah 31 orang (32,6\%), tidak berobat (karena sembuh sendiri) berjumlah 3 orang (3,2\%), tidak tahu harus melakukan apa 1 orang $(1,1 \%)$.Hal ini menunjukkan tindakan yang positif dari responden dimana sebagian besar membawa ke rumah sakit atau puskesmas terdekat.

\section{SIMPULAN}

Berdasarkan penelitian dan pembahasan maka dapat ditarik kesimpulan bahwa hal yang perlu diperhatikan yaitu pentingnya pengetahuan yang lebih dari masyarakat mengenai tungau debu rumah sehingga dapat mencegah peningkatan populasi tungau debu rumah di lingkungan masyarakat dan dapat mengetahui penanganan awal pada orang yang sensitif terhadap tungau debu sehingga dapat mengurangi angka mortalitas.

\section{UCAPAN TERIMA KASIH}

Ucapan terima kasih disampaikan pada dr. J. B. Bernadus, M.Biomed sebagai penguji 1, Dr. dr. Josef S. B. Tuda, Mkes, SpPar-K sebagai penguji 2, dan pada semua pihak yang baik secara langsung maupun tidak langsung telah menumbuhkan ide tau gagasan dalam pemikiran penulis sehingga dapat menyelesaikan artikel ini.

\section{DAFTAR PUSTAKA}

1. Faiza Arif. 2006. Hubungan Antara Lama Penggunaan Kasur Kapuk Dengan Jumlah Populasi Tungau Debu Rumah di Perumahan PJKA Kelurahan Randusari Semarang [Skripsi]. Semarang : Fakultas Kedokteran, Universitas Diponegoro Semarang.

2. Mitsugu M, Tetsuya T, Rikuodoi. 2010. The Effects of Reducing The Mite Allergen Level in The Residences on Bronchial Asthmatic 
Children. [internet]. [diunduh 2013 Juli 15] ; 571-574. Tersedia pada URL: http://www. icup.org.uk/reports\%5CICUP473.pdf.

3. Putra Negara Wisuda. 2007. Perbandingan Timbulnya Kekambuhan Rinitis Alergika Pada Penderita yang Menggunakan Kasur Kapuk dan Non Kapuk [Skripsi]. Semarang : Fakultas Kedokteran, Universitas Diponegoro Semarang.

4. Rofieq Ainur. 2012. Kajian Lingkungan Bahan Alergen Inhalan Debu Rumah Penduduk Perkotaan dan Pedesaan untuk Penyusunan Buku Pengelolaan Rumah Sehat [Internet]. [Diunduh 2013 Juli 18]. Tersedia pada URL: http:// karya ilmiah.um.ac.id/ index.php/disertasi/article/view/22566.

5. Anonym. Mencapai Kesehatan yang Baik dengan Kebersihan. Diakses Melalui: http://id.prmob.net/tungau-deburumah/kebersihan/karpet-589778.html, pada: 15 Januari 2013

6. Kariosentono Harijono. 2006. Dematitis Atopik (Eksema). Jawa Tengah: LPP UNS dan UPT Penerbitan dan Pencetakan UNS (UNS Press).

7. Satria Utama Denny. 2010. Hubungan Antara Jenis Aeroalergen Dengan Manifestasi Klinis Rinitis Alergika [Skripsi]. Semarang: Fakultas Kedokteran, Universitas Diponegoro Semarang. 